Local government in California 



\title{
LOCAL GOVERNMENT IN California
}

\author{
JOHN C. BOLLENS \\ $S T A N L E Y$ SCOTT
}

UNIVERSITY OF CALIFORNIA PRESS

BERKELEY AND LOS ANGELES $195^{1}$ 
UNIVERSITY OF CALIFORNIA PRESS

BERKELEY AND LOS ANGELES, CALIFORNIA

CAMBRIDGE UNIVERSITY PRESS, LONDON, ENGLAND COPYRIGHT, 1951, BY

THE REGENTS OF THE UNIVERSITY OF CALIFORNIA

PRINTED IN THE UNITED STATES OF AMERICA 